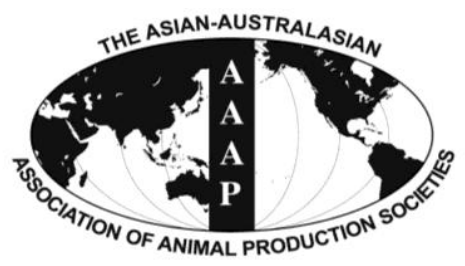

Asian-Aust. J. Anim. Sci.

Vol. 26, No. 1 : 82-89 January 2013

http://dx.doi.org/10.5713/ajas.2012.12347

www.ajas.info

pISSN 1011-2367 elSSN 1976-5517

\title{
Effects of Monensin on Metabolism and Production in Dairy Saanen Goats in Periparturient Period
}

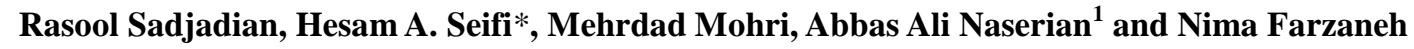 \\ Department of Clinical Sciences, School of Veterinary Medicine, Ferdowsi University of Mashhad, Mashhad, Iran
}

\begin{abstract}
This trial evaluated the effects of dietary supplementation with monensin sodium on dry matter intake, metabolic parameters and milk yield and milk composition of dairy Saanen goats in the periparturient period. Twelve Saanen pregnant dairy goats were assigned to a treatment and a control group. Saanen goats were fed monensin as its $10 \%$ sodium salt in the amount of $33 \mathrm{mg} / \mathrm{kg}$ of total dry matter intake during $30 \mathrm{~d}$ before parturition till d 42 in milk. Blood samples were collected from each goat at $\mathrm{d} 30,15$ and 7 before expected kidding time and also in $\mathrm{d} 1,7,13,19,21,28,35$ and 42 postpartum. The serum concentrations of $\beta$-Hydroxybutyrate (BHBA), non-esterifed fatty acid (NEFA), calcium, magnesium, inorganic phosphorus, cholesterol, triglyceride, urea, total protein, albumin and glucose and aspartate aminotransferase (AST) activity were determined. The BHBA concentration significantly decreased in goats, which received monensin in comparison to controls in the postpartum period $(p=0.049)$. The concentration of sodium $(\mathrm{Na})$ was significantly influenced by monensin treatment in the postpartum period $(p=0.048)$. In addition, the difference in dry matter intake was highly significant between the two groups during the pre-partum period. Controls had more dry matter intake (DMI) than treatment goats $(\mathrm{p}=0.0001)$. Mean $3.5 \%$ fat corrected milk production was not influenced by monensin treatment. However, milk fat percentage was significantly decreased in monensin treated goats $(\mathrm{p}=0.0017)$. (Key Words: Monensin, Dairy Goats, Saanen, Metabolism)
\end{abstract}

\section{INTRODUCTION}

Ketosis, as seen in dairy cows (ie, acetonaemia) or sheep (ie, pregnancy toxaemia), also may be encountered in goats (Harwood, 2004). Ketosis/pregnancy toxemia occurs in a doe (before or after kidding) because of an inability to consume enough feed to meet her needs. After kidding ketosis results from the doe producing higher milk yields than her body can sustain. The importance of ketosis in Saanen goats, which produce more milk, is greater than the other breeds of goats.

One potential way to help alleviate negative energy balance may be through the inclusion of ionophores. Ionophores act to alter the rumen microflora through ion transfer across cell membranes. One of the most commonly used ionophores is monensin (Tyler et al., 1992). Monensin has approved for use in lactating cows in many countries (Duffield et al., 2008). Monensin is a carboxylic polyether ionophore that is produced by the fermentation of

\footnotetext{
* Corresponding Author: Hesam A. Seifi. Tel: +98-511-8763851, Fax: +98-511-8763853, E-mail: haseifi@um.ac.ir

1 Department of Animal Sciences, Faculty of Agriculture, Ferdowsi University of Mashhad, Mashhad, Iran. Submitted Jun. 21, 2012; Accepted Sept. 15, 2012; Revised Oct. 4, 2012
}

Streptomyces cinnamonensis. It changes the rumen microflora, resulting in a decrease of the microbes that produce acetate and butyrate and increasing the microbes that produce propionate, the gluconeogenic precursor (Bergen and Bates, 1984). Monensin treatment in lactating dairy cattle reduced the blood concentrations of $\beta$-Hydroxybutyrate (BHBA), acetoacetate, and nonesterifed fatty acid (NEFA). These findings follow a logical pattern of improved, coordinated energy metabolism, which is particularly beneficial for the transition dairy cow in providing a more positive adaptive response to the challenges of lactation (Duffield et al., 2008). Furthermore, inclusion of monensin in lactating cow diets resulted in both increased milk yield and decreased DMI, and improved milk production efficiency (Duffield et al., 2008). Supplementation of monensin to pregnant ewes during prepartum period had a markedly positive influence on energy indicators in late pregnancy (Taghipoor et al., 2011). No milk withholding time and no pre-slaughter withdrawal period is required for monensin (Dick et al., 1996; Bagg et al., 2005).

The 1st objective of the study herein was to evaluate the metabolic effect of monensin administered $30 \mathrm{~d}$ before parturition till $42 \mathrm{~d}$ after parturition on serum biochemistry 
parameters in the weeks pre- and post-parturition in dairy Saanen goats. The 2 nd objective was to investigate the effects of monensin on dry matter intake, milk production and milk composition of Saanen goats.

\section{MATERIALS AND METHODS}

\section{Study design, animals and diets}

Twelve Saanen does were enrolled in an experimental trial. The does were synchronized for estrus by using two injections of PGF $2 \alpha 11 \mathrm{~d}$ apart. Rams were introduced to does $3 \mathrm{~d}$ after the second dose. The rams remained with does for one week. Pregnancy was diagnosed by ultrasonography on d 60 and 80 after mating using a portable B-mode ultrasound scanner. The number of fetuses was recorded during the ultrasonographic diagnosis of pregnancy. The health of all goats was examined by clinical examination and $\mathrm{CBC}$ analysis before the beginning of the study. The does were treated by Ivermectin and Triclabendazole for parasite control. Thirty days before expected time of parturition, the does were blocked by age and assumed fetal number and randomly divided into two groups. Animals in treatment group $(\mathrm{N}=6)$ received monensin as its $10 \%$ sodium salt at a rate of $33 \mathrm{mg} / \mathrm{kg} \mathrm{DM}$ that was mixed in their daily diet from $30 \mathrm{~d}$ before expected kidding time to $\mathrm{d} 42$ postpartum. Goats in control group ( $\mathrm{N}$ =6) did not receive monensin in their diet. All animals transferred to individual pens and were fed twice daily and fresh water was available ad-libitum. Both groups were fed the same pre-partum and post-partum rations. The diets were formulated to meet all nutrient requirements for pregnant does at pre-partum and lactating does during the postpartum period (NRC, 2007). The ingredients of prepartum and postpartum diets are shown in Table 1. Daily diet of each goat was weighed prior to feeding and feed refusals were measured by digital scale weigher for accurate estimation of daily DMI of each animal.

The does were weighed on $\mathrm{d} 30$ and 15 prior to parturition and on d 1, 15 and 30 postpartum. The kids were weighed at birth time.

\section{Sampling and biochemical analysis}

Blood samples were collected from the jugular vein of each goat at d 30, 15 and 7 before expected kidding time and also in hour 12 and $\mathrm{d}$ 7, 13, 19, 21, 28, 35 and 42 postpartum. Because of the difficulty in predicting parturition day, samples taken prior to kidding were grouped as d 29 prior to parturition ( $\mathrm{SD}=3.72), \mathrm{d} 14$ ( $\mathrm{SD}=$ $2.17)$, and d $6(\mathrm{SD}=1.97)$. All blood samplings were taken $3 \mathrm{~h}$ after first daily meal at the same time of day for all animals. The blood specimens were collected into $10 \mathrm{ml}$ vacuum tubes and were immediately transferred to laboratory with an unbroken cold chain. Each sample was
Table 1. Ingredients and chemical composition of the experimental diets

\begin{tabular}{lcc}
\hline & Pre-parturition & Post-parturition \\
\hline Feed intake (kg DM /d) & 1.7 & 2.054 \\
DMI (\% BW) & 3.4 & 4.86 \\
Ingredients (\% DM) & & \\
Alfalfa hay & 25 & 45 \\
Barely grain & 20 & 30 \\
Cottonseed meal & 9 & 10 \\
Wheat bran & 20 & 13.5 \\
Wheat straw & 25 & - \\
Vitamin & 1 & 0.5 \\
$\quad$ and mineral supplement & & \\
Lime & - & 0.7 \\
Salt & - & 0.3 \\
Chemical composition & & \\
Energy intake ME (Mcal/d) & 2.40 & 2.60 \\
CP (\% DM) & 13.1 & 15.5 \\
ADF (\% DM) & 27.4 & 21 \\
NDF (\% DM) & 44.9 & 34.5 \\
Ca (\% DM) & 0.62 & 0.9 \\
P (\% DM) & 0.61 & 0.6 \\
EE (\%) & 2.4 & 2.3 \\
\hline
\end{tabular}

centrifuged and its serum was harvested, frozen and stored at $-20^{\circ} \mathrm{C}$ until the time of analysis. The concentrations of BHBA and NEFA were determined by a D-3hydroxybutyrate kit and a NEFA Kit (Randox Laboratories Ltd, Ardmore, UK). Calcium, magnesium, inorganic phosphorus, cholesterol, triglyceride, urea, total protein, albumin and glucose concentrations and AST activity were determined by an automated biochemical analyzer (Biotecnica instruments, BT 1500, Rome, Italy) using commercial kits (Parsazmoon, Tehran, Iran). Sodium (Na) and potassium $(\mathrm{K})$ concentrations were determined by flame photometery (Elico, Model CL 361, India). Blood chemistry analysis was based on the following colorimetric methodologies, Total protein: Biuret reaction (Tomas, 1998), Albumin: Bromocresol green (Johnson et al., 1999), UREA: urease UV (Tomas, 1998), Cholesterol: CHOD-PAP (Deeg and Ziegenhorn, 1983), Magnesium: xylidyl blue-EGTA (Ratge et al., 1986), Phosphorus: phosphomolybdate UV (Daly and Ertingshausen, 1972), Calcium: arsenazo (Baginski et al., 1973), Glucose: glucose oxidase (Barham and Trinder, 1972), Triglyceride: GODPAP (Cole et al., 1997), AST: IFCC (Bergmeyer et al., 1986). BHBA (McMurray et al., 1984) and NEFA (DeVries et al., 1976) were measured with commercial colorimetric Kits. Measurement of data accuracy was done with the use of Control serum (Randox control sera, Antrim, UK). All parameters showed a within-run impression of less than $10 \%$ (Total protein: $0.95 \%$, Albumin: $0.91 \%$, UREA: $5.41 \%$, Cholesterol: <3\%, Magnesium: $1.2 \%$, Phosphorus: $1.87 \%$, 
Calcium: $1.45 \%$, Glucose: $<3 \%$, Triglyceride: $<3 \%$, AST: $2.5 \%$, BHBA: $<5 \%$ and NEFA: $<5 \%)$.

$\mathrm{CBC}$ analysis was performed in $\mathrm{d} 30,15$ and 7 before parturition and $\mathrm{d} 3,10,20$ and 35 postpartum for monitoring health status of animals. Blood specimens for $\mathrm{CBC}$ analysis were collected in EDTA containing tubes and analyzed by an automated cell counter (Nihon Kohden, Tokyo, Japan).

After parturition, all animals were machine-milked twice daily and the milk yield of each doe was recorded. Also in d 5, 20, 35 and 50 of lactation, milk specimens were collected and frozen for analysis of milk composition. Milk composition analysis was done by milk analyzer (Lactostar, TMS Ltd., Germany).

\section{Data management and statistical analysis}

The data were checked for errors and compared with written reports; outliers were rechecked to ensure that values were accurate. Because serum metabolites were measured over time, a repeated measures approach using ANOVA with Mixed linear models (PROC MIXED) was used in SAS (The SAS system for Windows, Version 8.2, Cary, NC, USA). All outcome variables were screened for normality by visual assessment of the distributions and calculation of kurtosis and skewness. The distributions of cholesterol, albumin, total protein, calcium, inorganic phosphorus, magnesium, sodium and potassium were normal. Serum concentrations of BHBA, NEFA, glucose, triglyceride, urea, and AST were skewed to the right. Therefore, a logarithmic transformation was performed on each of these dependent variables, which resulted in a normal distribution. Goat variables included treatment, age, and the number of fetuses, and body weight at sampling time (except for the models in which body weight was the outcome). Age as a covariate variable was classified as 1 , less than 3 yrs old and 2, equal to or more than 3 yrs. Goats that had a body weight equal or less than $45 \mathrm{~kg}$ were classified as thin, a body weight of greater than $45 \mathrm{~kg}$ as fair.

The metabolites and DMI were separately analysed at pre-partum and postpartum periods. Body weight, milk production, milk fat percentage, milk fat yield, milk protein percentage, and milk protein yield were considered as outcome variables. Outcome variables were treated as repeated measures within goat in PROC MIXED. Age as a covariate variable was considered for milk yield and milk components. Several covariance structures were evaluated for each outcome: compound symmetry, unstructured, auto regressive order 1 , autoregressive heterogeneous order 1 , topelitz and topelitz heterogeneous. The covariance structure that resulted in Akaike's information criterion (AIC) closest to zero was used (Wang and Goonewardene, 2004).

Preliminary Mixed models were used to screen for significant variables and their interactions with monensin. The interaction term was removed from the model when $\mathrm{p}>$ 0.25. A final model for each outcome variable was built using manual backward elimination procedure with a pvalue of $<0.05$ for a partial F-test. All reported values are least squares means.

\section{RESULTS}

Animals, twinning, body weight of kids, and feed intake

The average age of goats was $3.92 \pm 3.01 \mathrm{yr}$ (range: 2 to $10 \mathrm{yr}$ ) and $3.58 \pm 3.22 \mathrm{yr}$ (range: 1.5 to $10 \mathrm{yr}$ ) in monensinfed and control groups, respectively. The mean body weight of goats $30 \mathrm{~d}$ ante-partum was $52.45 \pm 11.24 \mathrm{~kg}$ in monensin treated group and $41.57 \pm 9.73 \mathrm{~kg}$ in controls. One day postpartum, does in treatment group weighed 51.05 \pm 11.74 $\mathrm{kg}$ and does in control group weighed $41.60 \pm 10.70$. At $30 \mathrm{~d}$ after kidding the mean body weight of treatment and control groups were $46.70 \pm 10.69 \mathrm{~kg}$ and $37.97 \pm 6.39 \mathrm{~kg}$, respectively. Although the body weight difference between two groups was remarkable, it was not statistically significant. In addition, differences of age and weight gains during samplings between groups were not statistically significant.

Four out of 6 does in treatment group and two out of 6 controls bore twin kids. The mean body weight of kids in treatment group was $3.00 \pm 0.214 \mathrm{~kg}$ and in control group was $2.830 \pm 0.222 \mathrm{~kg}$. The difference of body weight of neonatal kids between groups was not significant.

Treatment group fed 1,333.66 $\pm 39 \mathrm{~g}$ dry matter/d and control group fed $1,481 \pm 30 \mathrm{~g}$ dry matter/d during $30 \mathrm{~d}$ prepartum. The difference of dry matter intake was highly significant $(\mathrm{p}=0.0001)$ between two groups pre-partum (Table 2). The controls with less body weight received more DMI. Therefore, body weight was not an influencing factor on the significant difference between two groups. However,

Table 2. Comparison of least square of means (LSMs) and standard errors (SE) of dry matter intake between Saanen does receiving monensin and the controls which did not received it

\begin{tabular}{|c|c|c|c|c|c|c|}
\hline & \multicolumn{2}{|c|}{ Groups } & \multirow{2}{*}{ Pooled SE } & \multicolumn{3}{|c|}{$\mathrm{p}$ values } \\
\hline & Monensin & Control & & $\mathrm{M}$ & $\mathrm{T}$ & $\mathrm{M} \times \mathrm{T}$ \\
\hline Periparturition period $(\mathrm{g} / \mathrm{d})$ & $1,751.31$ & $1,791.90$ & 40.89 & 0.47 & 0.99 & 0.99 \\
\hline Pre-partum (g/d) & $1,333.66$ & $1,481.02$ & 30.50 & 0.0001 & 0.81 & 0.95 \\
\hline Post-partum (g/d) & $2,060.40$ & $2,048.58$ & 48.34 & 0.84 & $<0.0001$ & 0.66 \\
\hline
\end{tabular}


Table 3. Comparison of least square of means (LSMs) and standard errors (SEs) of serum constituents among pregnant Saanen goats receiving monensin and Controls not fed monensin during the pre-parturition period (within $30 \mathrm{~d}$ before parturition) ${ }^{1}$

\begin{tabular}{|c|c|c|c|c|c|c|c|c|c|c|}
\hline \multirow{2}{*}{ Metabolites } & \multicolumn{2}{|c|}{ D 30} & \multicolumn{2}{|c|}{ D 15} & \multicolumn{2}{|c|}{ D 7} & \multirow{2}{*}{$\begin{array}{c}\text { Pooled } \\
\text { SE }\end{array}$} & \multicolumn{3}{|c|}{$\mathrm{p}$ values } \\
\hline & Monensin & Control & Monensin & Control & Monensin & Control & & $\mathrm{M}$ & $\mathrm{T}$ & $\mathrm{T} \times \mathrm{M}$ \\
\hline$\overline{\mathrm{BHBA}}(\mathrm{mmol} / \mathrm{L})$ & 0.140 & 0.180 & 0.141 & 0.153 & 0.121 & 0.172 & 0.150 & 0.17 & 0.75 & 0.59 \\
\hline NEFA (mmol/L) & 0.400 & 0.330 & 0.411 & 0.376 & 0.331 & 0.475 & 0.170 & 0.86 & 0.85 & 0.25 \\
\hline Glucose (mmol/L) & 2.302 & 1.975 & 1.696 & 2.276 & 2.727 & 2.269 & 0.008 & 0.93 & 0.11 & 0.09 \\
\hline Cholesterol (mmol/L) & 2.286 & 2.497 & 2.447 & 2.843 & 2.496 & 2.637 & 0.238 & 0.42 & 0.20 & 0.65 \\
\hline Triglycerides (mmol/L) & 0.186 & 0.237 & 0.598 & 0.457 & 0.239 & 0.322 & 0.003 & 0.76 & 0.00 & 0.51 \\
\hline $\operatorname{AST}(\mathrm{u} / \mathrm{L})$ & 91.909 & 73.965 & 96.795 & 74.017 & 89.255 & 77.068 & 0.110 & 0.20 & 0.80 & 0.37 \\
\hline Albumin (g/L) & 33.094 & 32.036 & 35.961 & 34.770 & 34.147 & 37.220 & 1.850 & 0.89 & 0.12 & 0.34 \\
\hline T. Protein (g/L) & 65.165 & 65.292 & 66.215 & 69.692 & 64.508 & 69.292 & 5.940 & 0.72 & 0.67 & 0.74 \\
\hline Urea (mmol/L) & 18.031 & 16.045 & 18.010 & 15.626 & 15.504 & 16.561 & 0.170 & 0.50 & 0.63 & 0.24 \\
\hline Calcium (mmol/l) & 2.724 & 2.407 & 2.738 & 2.706 & 2.624 & 2.788 & 0.175 & 0.74 & 0.52 & 0.29 \\
\hline I. Phosphorus (mmol/L) & 1.993 & 2.050 & 2.708 & 2.399 & 2.254 & 2.419 & 0.230 & 0.93 & 0.02 & 0.41 \\
\hline Magnesium (mmol/L) & 1.085 & 1.050 & 1.186 & 1.147 & 1.070 & 1.260 & 0.108 & 0.78 & 0.22 & 0.15 \\
\hline Sodium $(\mathrm{mEq} / \mathrm{L})$ & 137.00 & 138.33 & 144.00 & 135.50 & 142.50 & 136.00 & 3.060 & 0.26 & 0.46 & 0.02 \\
\hline Potassium (mEq/L) & 4.18 & 4.29 & 4.21 & 4.40 & 4.30 & 4.35 & 0.135 & 0.43 & 0.73 & 0.85 \\
\hline
\end{tabular}

${ }^{1}$ The $\mathrm{p}$ values of the effects of monensin, time $(\mathrm{T})$ and the interaction of monensin and time $(\mathrm{M} \times \mathrm{T})$ are shown.

the mean daily dry matter intake was $2,060.4 \pm 53 \mathrm{~g}$ in monensin group and 2,048.6 $\pm 58 \mathrm{~g}$ in controls during $42 \mathrm{~d}$ in milk $(\mathrm{p}=0.84)$.

\section{Serum biochemical analysis}

No significant effect of monensin was seen on the concentration of BHBA pre-partum (Table 3). However, the concentration of BHBA was significantly affected by monensin treatment in the postpartum period (Table 4). The BHBA concentration significantly $(\mathrm{p}=0.049)$ decreased in does which received monensin in comparison to the control group after parturition (Figure 1).

No significant effect of monensin was seen on the concentrations of NEFA, glucose, cholesterol, triglyceride and activities of AST at prepartum and postpartum periods.

The concentration of $\mathrm{Na}$ was significantly influenced by monensin treatment $(p=0.048)$ after parturition (Table 4$)$. No significant monensin effects were found for albumin, total protein, urea, calcium, inorganic phosphorus, magnesium and $\mathrm{K}$ in pre- and post-partum periods (Tables 3 and 4).

\section{Milk production and components}

Mean $3.5 \%$ fat corrected milk production was not influenced by monensin treatment. Milk fat percentage was significantly $(p=0.0017)$ decreased in monensin treated goats in comparison with the control group (Figure 2). The milk fat and protein yields and percentages of milk protein, milk lactose and milk dry matter (g/daily) was not influenced by monensin (Table 5).

\section{DISCUSSION}

The main objective of the study presented here was to explore potential effects of monensin supplementation during the last month of pregnancy and $42 \mathrm{~d}$ of lactation on

Table 4. Comparison of least square of means (LSMs) and standard errors (SEs) of serum constituents among lactating Saanen goats receiving monensin and controls not fed monensin during the post-parturition period (within $42 \mathrm{~d}$ after parturition) ${ }^{1}$

\begin{tabular}{|c|c|c|c|c|c|c|c|c|c|c|c|c|c|c|c|c|c|c|c|c|}
\hline \multirow{2}{*}{ Metabolites } & \multicolumn{2}{|c|}{$\mathrm{H}+12$} & \multicolumn{2}{|c|}{$D+7$} & \multicolumn{2}{|c|}{$\mathrm{D}+13$} & \multicolumn{2}{|c|}{$\mathrm{D}+19$} & \multicolumn{2}{|c|}{$\mathrm{D}+21$} & \multicolumn{2}{|c|}{$\mathrm{D}+28$} & \multicolumn{2}{|c|}{$\mathrm{D}+35$} & \multicolumn{2}{|c|}{$\mathrm{D}+42$} & \multirow{2}{*}{$\begin{array}{l}\text { Pooled } \\
\text { SE }\end{array}$} & \multicolumn{3}{|c|}{$\mathrm{p}$ values } \\
\hline & M & $\mathrm{C}$ & M & $\mathrm{C}$ & M & $\mathrm{C}$ & M & $\mathrm{C}$ & M & $\mathrm{C}$ & M & $\mathrm{C}$ & M & $\mathrm{C}$ & M & $\mathrm{C}$ & & M & $\mathrm{T}$ & $T \times M$ \\
\hline $\mathrm{BHBA}(\mathrm{mmol} / \mathrm{L})$ & 0.140 & 0.267 & 0.217 & 0.245 & 0.181 & 0.440 & 0.300 & 0.468 & 0.302 & 0.470 & 0.235 & 0.429 & 0.197 & 0.365 & 0.280 & 0.340 & 0.214 & 0.05 & 0.00 & 0.32 \\
\hline NEFA (mmol/L) & 0.339 & 0.405 & 0.314 & 0.368 & 0.291 & 0.450 & 0.332 & 0.263 & 0.302 & 0.224 & 0.133 & 0.291 & 0.106 & 0.247 & 0.133 & 0.204 & 0.463 & 0.65 & 0.01 & 0.43 \\
\hline Glucose (mmol/L) & 3.20 & 3.30 & 2.85 & 2.70 & 2.24 & 2.67 & 2.48 & 2.47 & 2.28 & 2.84 & 2.88 & 3.25 & 3.01 & 3.34 & 2.83 & 3.09 & 0.008 & 0.54 & 0.08 & 0.94 \\
\hline Cholesterol (mmol/L) & 2.350 & 2.600 & 2.524 & 2.569 & 2.469 & 2.878 & 2.468 & 2.664 & 2.798 & 2.718 & 2.499 & 2.918 & 2.495 & 3.117 & 3.103 & 3.766 & 0.299 & 0.29 & 0.00 & 0.46 \\
\hline Triglycerides (mmol/L) & 0.039 & 0.069 & 0.072 & 0.071 & 0.136 & 0.114 & 0.094 & 0.044 & 0.043 & 0.088 & 0.047 & 0.102 & 0.097 & 0.118 & 0.044 & 0.111 & 0.004 & 0.25 & 0.44 & 0.46 \\
\hline AST (u/L) & 112.26 & 103.20 & 107.44 & 100.46 & 100.012 & 110.91 & 96.99 & 101.03 & 100.95 & 99.81 & 149.61 & 100.17 & 99.81 & 101.34 & 122.18 & 111.46 & 0.141 & 0.78 & 0.04 & 0.04 \\
\hline Albumin $(\mathrm{g} / \mathrm{L})$ & 33.23 & 33.59 & 35.360 & 35.62 & 35.68 & 37.438 & 35.98 & 33.60 & 37.56 & 32.95 & 35.89 & 33.70 & 36.13 & 34.97 & 38.29 & 36.30 & 2.83 & 0.63 & 0.12 & 0.30 \\
\hline T. Protein & 64.620 & 69.81 & 70.90 & 77.14 & 72.55 & 85.31 & 72.82 & 76.12 & 75.75 & 76.27 & 70.603 & 77.522 & 71.00 & 73.36 & 74.80 & 75.59 & 7.41 & 0.59 & 0.00 & 0.14 \\
\hline Urea $(\mathrm{mmol} / \mathrm{L})$ & 15.81 & 12.99 & 17.47 & 15.55 & 16.54 & 17.38 & 19.39 & 17.01 & 20.24 & 18.22 & 18.40 & 17.30 & 16.0 & 15.54 & 17.99 & 16.55 & 0.121 & 0.59 & 0.04 & 0.92 \\
\hline Calcium (mmol/L) & 2.762 & 2.437 & 2.964 & 2.913 & 2.824 & 2.521 & 2.670 & 2.347 & 2.608 & 2.527 & 2.505 & 2.589 & 2.478 & 2.485 & 2.569 & 2.419 & 0.171 & 0.33 & 0.03 & 0.70 \\
\hline I.Phosphorus (mmol/L) & 2.057 & 1.462 & 1.960 & 2.133 & 1.781 & 2.403 & 2.141 & 2.080 & 2.085 & 2.070 & 2.323 & 2.201 & 1.866 & 2.162 & 2.238 & 1.911 & 0.387 & 0.97 & 0.61 & 0.22 \\
\hline Magnesium (mmol/L) & 1.161 & 1.293 & 1.083 & 1.256 & 1.146 & 1.246 & 1.102 & 1.082 & 1.132 & 1.227 & 1.148 & 1.133 & 1.081 & 1.240 & 0.892 & 1.177 & 0.185 & 0.68 & 0.17 & 0.42 \\
\hline Sodium $(\mathrm{mEq} / \mathrm{L})$ & 143.35 & 140.73 & 147.52 & 143.23 & 141.52 & 136.23 & 138.85 & 135.73 & 146.85 & 138.73 & 146.52 & 138.40 & 145.52 & 138.40 & 146.85 & 139.56 & 3.425 & 0.05 & 0.15 & 0.94 \\
\hline Potassium $(\mathrm{mEq} / \mathrm{L})$ & 4.25 & 4.17 & 4.19 & 3.99 & 3.79 & 3.64 & 4.07 & 3.91 & 4.10 & 3.89 & 4.20 & 3.81 & 4.09 & 3.97 & 4.17 & 3.96 & 0.16 & 0.12 & 0.11 & 0.98 \\
\hline
\end{tabular}

${ }^{1}$ The $\mathrm{p}$ values of the effects of monensin, time $(\mathrm{T})$ and the interaction of monensin and time $(\mathrm{M} \times \mathrm{T})$ are shown. 


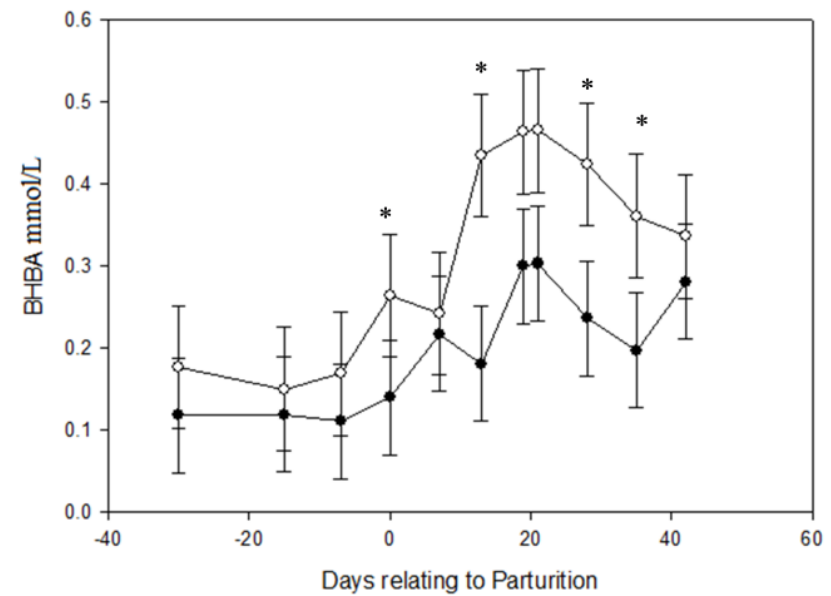

Figure 1. Least square of means values and standard errors for serum BHBA $(\mathrm{mmol} / \mathrm{L})$ concentration at $30 \mathrm{~d}$ before parturition till $42 \mathrm{~d}$ in milk in Saanen goats receiving monensin (•), and not receiving monensin $(\circ)$. Significant timextreatment interactions $(\mathrm{p}<0.05)$ on $\mathrm{d} 1,13,28$ and 35 were showed by an asterisk.

serum biochemistry and milk production of dairy Saanen does. Comparison of serum biochemical constituents showed significant differences of BHBA and $\mathrm{Na}$ concentrations between treatment and control groups. To the knowledge of the authors, there is only one peer reviewed paper on the effect of monensin on milk composition and ruminal volatile fatty acids present in lactating goats (Brown and Hogue, 1985).

The administration of monensin to pregnant Saanen goats during $30 \mathrm{~d}$ before expected parturition till $42 \mathrm{~d}$ of lactation significantly reduced BHBA concentration when compared with a control group in post-partum period. This finding is consistent with results from monensin supplemented dairy cows (Petersson-Wolfe et al., 2007; Duffield et al., 2008). The beneficial effect of monensin on negative energy balance was seen in pre-partum period in ewes (Austin and Wilde, 1985; Taghipoor et al., 2011); however, the hypoketonemic impact of monensin was more prominent in the lactation period during $\mathrm{d} 1,13,28$ and 35

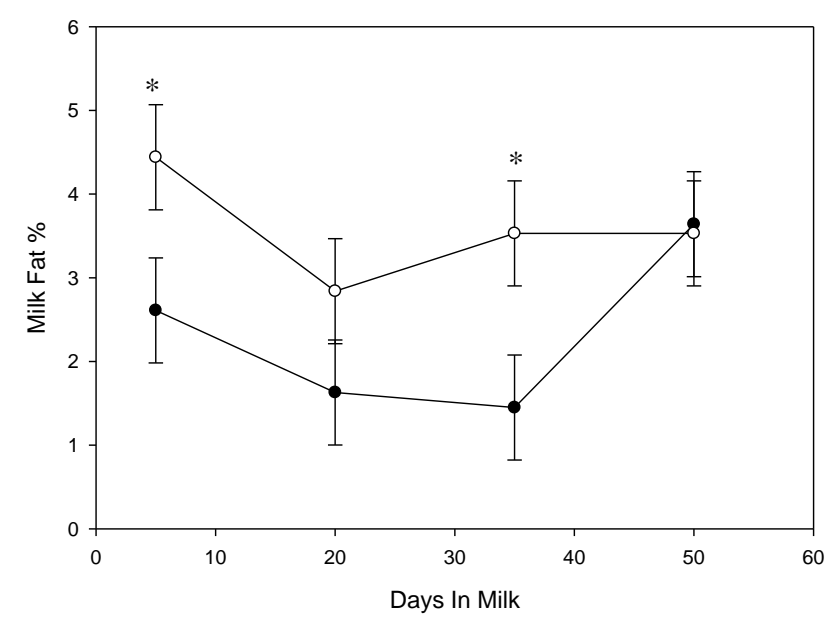

Figure 2. Least square of means values and standard errors for milk fat percent during $50 \mathrm{~d}$ in milk in Saanen goats receiving monensin (•), and not receiving monensin (०). Significant timextreatment interactions $(\mathrm{p}<0.05)$ were showed by an asterisk.

postpartum in dairy Saanen goats. This finding is similar to the results obtaining in dairy cows (Duffield et al., 2008). It is reasonable to expect the effects of monensin on energy metabolism to occur in prepartum ewes in contrast to dairy goats where the greater effects were seen in the postparturition period. Negative energy balance appears to be related to the glucose demands of lactation in dairy goats similar to that of dairy cows. However, in pregnant ewes the glucose utilization of fetal-placental unit is the major glucose demanding mechanism as eighty percent of fetal growth occurs during the last 6 wks of gestation in sheep (Edmondson and Pugh, 2009).

One of the major beneficial mechanisms of monensin on energy metabolism is increasing of propionate production in the rumen by inducing an alteration in rumen microflora (an increase in gram negative bacteria and a decrease in gram positive bacteria). While propionate is the major precursor of gluconeogenesis, more propionate production leads to a better function of this metabolic pathway. The end product of this pathway is glucose. Since

Table 5. Comparison of least square of means (LSMs) and standard errors (SE) of milk composition parameters between Saanen does receiving monensin and controls not receiving it

\begin{tabular}{|c|c|c|c|c|c|c|c|c|c|c|c|c|}
\hline \multirow{2}{*}{$\begin{array}{l}\text { Milk yield } \\
\text { and components }\end{array}$} & \multicolumn{2}{|c|}{$\mathrm{D}+5$} & \multicolumn{2}{|c|}{$\mathrm{D}+20$} & \multicolumn{2}{|c|}{$\mathrm{D}+35$} & \multicolumn{2}{|c|}{$\mathrm{D}+50$} & \multirow{2}{*}{$\begin{array}{l}\text { Pooled } \\
\text { SE }\end{array}$} & \multicolumn{3}{|c|}{$\mathrm{p}$ values } \\
\hline & Monensin & Control & Monensin & Control & Monensin & Control & Monensin & Control & & $\mathrm{M}$ & $\mathrm{T}$ & $\mathrm{T} \times \mathrm{M}$ \\
\hline $\begin{array}{l}\text { Milk yield 3.5\% FCM }{ }^{1} \\
(\mathrm{~g} / \mathrm{d})\end{array}$ & $1,457.34$ & $2,354.26$ & $1,762.40$ & $1,697.66$ & $1,677.16$ & $2,199.57$ & $3,253.00$ & $2,312.64$ & 504.96 & 0.842 & 0.061 & 0.139 \\
\hline $\mathrm{SCM}^{2}$ yield $(\mathrm{g} / \mathrm{d})$ & $1,374.84$ & $2,219.99$ & $1,616.95$ & $1,548.24$ & $1,635.06$ & $2,007.09$ & $2,977.51$ & $2,049.28$ & 444.37 & 0.905 & 0.067 & 0.097 \\
\hline Fat yield $(\mathrm{g} / \mathrm{d})$ & 40.663 & 91.613 & 42.550 & 65.176 & 32.767 & 78.704 & 123.760 & 68.599 & 21.599 & 0.365 & 0.164 & 0.045 \\
\hline Fat $(\%)$ & 2.608 & 4.443 & 1.626 & 2.841 & 1.451 & 3.526 & 3.636 & 3.533 & 0.627 & 0.001 & 0.105 & 0.368 \\
\hline Protein yield (g/d) & 51.962 & 67.453 & 77.307 & 65.70 & 73.78 & 69.72 & 105.55 & 62.60 & 13.83 & 0.49 & 0.17 & 0.035 \\
\hline Protein $(\%)$ & 3.275 & 3.586 & 2.901 & 3.095 & 3.155 & 3.116 & 3.306 & 2.858 & 0.139 & 0.970 & 0.009 & 0.024 \\
\hline Lactose yield (g/d) & 4.648 & 5.142 & 4.196 & 4.491 & 4.561 & 4.674 & 4.758 & 4.584 & 0.158 & 0.167 & 0.002 & 0.194 \\
\hline Lactose $(\%)$ & 4.691 & 5.171 & 4.240 & 4.52 & 4.61 & 4.70 & 4.80 & 4.61 & 0.15 & 0.271 & 0.002 & 0.086 \\
\hline $\mathrm{SNF}^{3}$ yield $(\mathrm{g} / \mathrm{d})$ & 138.150 & 178.870 & 207.080 & 177.0 & 197.330 & 192.740 & 280.910 & 182.020 & 36.819 & 0.583 & 0.097 & 0.047 \\
\hline SNF (\%) & 8.685 & 9.525 & 7.793 & 8.311 & 8.423 & 8.556 & 8.808 & 8.298 & 0.295 & 0.409 & 0.001 & 0.054 \\
\hline
\end{tabular}

${ }^{1} \mathrm{FCM}=$ Fat corrected milk. ${ }^{2} \mathrm{SCM}=$ Solids corrected milk. ${ }^{3} \mathrm{SNF}=$ Solids not fat. 
the ketone bodies suppress the endogenous glucose production, monensin can indirectly cause elevation of blood glucose concentration by lowering ketone bodies (Schlumbohm et al., 2004). The increased concentration of glucose was not seen in monensin-fed goats in the present study. The finding that glucose concentration was increased with monensin has not been consistently reported in the literature. The lack of a significant effect of monensin on glucose concentration most likely is a function of the response being small and generally requiring a larger sample size to effectively assess the glucose response (Duffield et al., 2008).

Monensin could also reduce BHBA by reducing butyrate in the rumen, which is converted to BHBA in the rumen epithelium. A rise in BHBA occurs after meals, which is believed to be a result of an increase in conversion of butyrate into BHBA in the rumen epithelium (Plaizier et al., 2005).

Other energy and protein biochemical indicators particularly NEFA and cholesterol were frequently not significant possibly due to the large number of subjects needed to show statistically significant effect (Duffield et al., 2008).

There was a significantly higher $\mathrm{Na}$ concentration in goats receiving monensin. The basic mode of action of monensin and other ionophores is to modify the movement of ions across biological membranes. This basic function has yielded the name ionophore or "ion bearer" (Schelling, 1984). The effectiveness of monensin to cause Na entry into cells has been well established (Smith and Rosengurt, 1978), and other reported cellular ion changes may be secondary to the primary $\mathrm{Na}$ effect (Schanne et al., 1979). Scott et al. (1984) showed that monensin increased apparent absorption of sodium in steers. In agreement with the present study, Lasalocid (another ionophore) supplementation significantly increased serum $\mathrm{Na}$ concentration during late pregnancy and during lactation in Rambouillet ewes (Shetaewi and Ross, 1991). However, this effect of monensin on $\mathrm{Na}$ in dairy cows and ewes was not reported in previously published papers (Austin and Wilde, 1985; Taghipoor et al., 2011). The biological significance of the finding is not obvious and it might be a random effect. Furthermore, the serum $\mathrm{Na}$ concentration remained within the normal range throughout the experimental period.

In the current study DMI was lower for Saanen does receiving monensin than does serving as controls $(\mathrm{p}=$ 0.0001 ) during the prepartum period. However DMI was not significantly different between two groups at postpartum period. Although the body weight difference between two groups was remarkable, it was not statistically significant. It is noteworthy that the controls with less body weight received more DMI. Therefore, body weight was not an influencing factor on significant increase of DMI in controls versus treatment group. On the other hand, body weight was considered as a covariate in statistical analysis of serum metabolites and DMI.

The impact of monensin on DMI in dairy cattle is inconsistent in the literature. A meta-analysis of the effect of monensin on production outcomes in dairy cattle, conducted using 77 trials, indicated significantly decreased dry matter intake by $0.3 \mathrm{~kg}$ (Duffield et al., 2008).

The work by Sauer et al. (1989) reported a decrease in DMI in cows treated with $33 \mathrm{ppm}$ of monensin during early lactation. Wagner et al. (1999) also showed decreased DMI during the whole lactation period with monensin at the level of 16 and $24 \mathrm{ppm}$. However, in one review, the authors found that 8 of 12 studies on ionophores reported no significant difference for DMI (Ipharraguerre and Clark, 2003).

Our results showed significant DMI decrease only at pre-partum and not at post-partum period. Schelling (1984) indicated that severe feed depression was seen when abruptly introducing cattle to monensin, which reduced feed intake by as much as $16 \%$. Studies indicate depressions of less than $5 \%$ after $112 \mathrm{~d}$ on feed (Schelling, 1984).

The finding on DMI during the post-partum period is also consistent with results obtained by Brown et al. (1985) in French Alpine does and results of Petersson-wolfe et al. (2007) in cows. Petersson-Wolfe et al. (2007) have reported no significant impact of monensin delivered with controlled- release capsule and as feed additive on DMI in dairy cows in the transition period. In a study on the effect of monensin in lactating goats, no significant effect of monensin was seen on feed intake (Brown and Hogue, 1985).

The influence of monensin on digestibility is variable and the response is often unfavourable during adaptation periods. Several studies suggest that monensin may initially produce a negative effect followed by a slight positive effect. Simpson (1978) found that monensin decreased cellulose digestibility when no adaptation time was allowed, but reports indicate that monensin had no effect on cellulose digestibility when animals had been adapted to monensin for $21 \mathrm{~d}$ (Dinius et al., 1976). A reduction in dry matter and ADF digestibility was observed when lambs were fed monensin for only $10 \mathrm{~d}$, but after an additional $29 \mathrm{~d}$ of adaptation, there was no significant difference (Poos et al., 1979).

Monensin impact on milk yield and milk components were extensively studied in dairy cows (Beckett et al., 1998; Duffield et al., 2000; Dubuc et al., 2010). No monensin effect on milk yield was detected in the present study. This is in agreement with Brown and Hogue (1985) results which, fed monensin to French Alpine lactating goats. Results on the effects of monensin on milk production in dairy cows are, however, inconsistent in the literature. Some 
studies have reported that monensin increased milk production, but others have not (Duffield et al., 2008). The increasing effect has been attributed to an increased supply of glucogenic precursors resulting from changes in the pattern of rumen fermentation (Phipps et al., 2000).

There is conflicting evidence on the effect of monensin supplementation on milk fat and protein. Monensin treatment decreased milk fat percentage by 1.25 percentage point and milk fat yield by $16 \mathrm{~g} / \mathrm{d}$ (Table 5). This decreasing effect of monensin on milk fat percentage is in relative agreement with the results of meta-analysis by Duffield et al. (2008) in dairy cows. In addition, they found no effect of monensin on milk fat yield, which is similar to our results. The decreasing effect of monensin on milk fat could be explained by the fact that monensin causes a reduction of rumen biohydrogenation of long-chain fatty acids (Fellner et al., 1997), resulting in the production of specific fatty acid isomers (Bauman and Griinari, 2003) that inhibit milk fat synthesis in the mammary gland (Baumgard et al., 2000).

Monensin did not significantly alter milk protein yield and percentage in our study. These results were similar to those of Sauer et al. (1989), Beckett et al. (1998), and Duffield et al. (2000) in dairy cattle. No monensin supplementation effect was found on milk lactose percentage.

\section{CONCLUSIONS}

To the knowledge of authors this is the first comprehensive evaluation of the impact of monensin on metabolic parameters, dry matter intake and milk production in periparturient dairy goats. Monensin reduced serum BHBA concentration in the postpartum period. However, this improved energy metabolism did not result in increased milk production or improved dry matter intake. On the other hand, milk fat percentage significantly decreased in Monensin fed goats, which is not desirable quality for goat milk. Monensin significantly decreased DMI during the pre-partum period. However, Monensin is a promising tool for improving the energy status of dairy goats during transition period. Further work will be needed to document any potential health or performance benefits attributable to this improved energy supply.

\section{ACKNOWLEDGEMENT}

This study was supported by research fund of Ferdowsi University of Mashhad (Project number: 364, 88/9/24).

\section{REFERENCES}

Austin, A. R. and R. M. Wilde. 1985. The effect of sodium monensin in pregnant ewes. Br. Vet. J. 141:628-634.
Bagg, R., C. P. Vessie, C. P. Dick, T. Duffield, J. B. Wilson and J. J. Aramini. 2005. Milk residues and performance of lactating dairy cows administered high doses of monensin. Can. J. Vet. Res. 69:180-185.

Baginski, E. S., S. S. Marie, W. L. Clark and B. Zak. 1973. Direct microdetermination of serum calcium. Clin. Chem. Acta. 46:46-54

Barham, D. and P. Trinder. 1972. An improved color reagent for the determination of blood glucose by the oxidase system. Analyst 97:142-145.

Bauman, D. E. and J. M. Griinari. 2003. Nutritional regulation of milk fat synthesis. Annu. Rev. Nutr. 23:203-227.

Baumgard, L. H., B. A. Corl, D. A. Dwyer, A. Saeb and D. A. Bauman. 2000. Identification of the conjugated linoleic acid isomer that inhibits milk fat synthesis. Am. J. Phys. 278:R179R184.

Beckett, S., I. Lean, R. Dyson, W. Tranter and L. Wade. 1998. Effects of monensin on the reproduction, health, and milk production of dairy cows. J. Dairy Sci. 81:1563-1573.

Bergen, W. G. and D. B. Bates. 1984. Ionophores: Their effect on production efficiency and mode of action. J. Anim. Sci. 58:1465-1483.

Bergmeyer, H. N., M. Horder and R. Rej. 1986. International federation of clinical chemistry (IFCC) scientific committee analytical section: approved recommendation on IFCC method for measurement of catalytic concentration of enzyme, part 2: IFCC method for aspartate aminotransferase. J. Clin. Chem. Clin. Biochem. 24:497-510.

Brown, D. L. and O. E. Hogue. 1985. Effects of feeding monensin sodium to lactating goats: milk composition and ruminal volatile fatty acids, Cornell University. J. Dairy Sci. 68:11411147.

Cole, T. G., S. G. Klotzch and J. McNamara. 1997. Measurement of triglyceride concentration. In: Handbook of Lipoprotein Testing (Ed. N. Rifai, G. R. Warnick, M. H. Dominiczak). AACC press, Washington, pp. 115-126.

Daly, J. A. and G. Ertingshausen. 1972. Direct method for determining inorganic phosphate in serum with the "CentrifiChem". Clin. Chem. 18:263-265.

Deeg, R. and J. Ziegenhorn. 1983. Kinetic enzymatic method for automated determination of total cholesterol in serum. Clin. Chem. 29:1798-1802.

DeVries, G. H., P. Mamunes, C. D. Miller and D. M. Hayward. 1976. Quantitative determination of C6:O-C18:3 serum nonesterified fatty acids by gas-liquid chromatography. Anal. Biochem. 70:156-166.

Dick, C. P., G. V. Vessie, J. W. Moran and M. Coleman. 1996. The determination of monensin residues in cattle following the administration of two monensin controlled release capsules. Proceedings of the World Buiatrics Congress, Edinburgh, 254.

Dinius, D. A., M. S. Simpson and P. B. Marsh. 1976. Effect of monensin fed with forage on digestion and the ruminal ecosystem of steers. J. Anim. Sci. 42:229-234.

Dubuc, J., D. DuTremblay, J. Baril, R. Bagg, M. Brodeur, T. Duffield and L. DesCôteaux. 2010. A field study on the effects of dietary monensin on milk production and milk composition in dairy cows. Can. Vet. J. 51:375-379.

Duffield, T. F. and R. Bagg. 2000. Use of Ionophores in lactating dairy cattle: A review. Can. Vet. J. 41:388-394. 
Duffield, T. F., A. R. Rabiee and I. J. Lean. 2008. A meta-analysis of the impact of monensin in lactating dairy cattle. Part 1. metabolic effects. J. Dairy Sci. 91:1334-1346.

Edmondson, M. A. and D. G. Pough. 2009. Pregnancy toxemia in sheep and goats. In: Current Veterinary Therapy Food Animal Practice, 5th Ed. Saunders, St. Louis, pp. 144-145.

Fellner, V., F. D. Sauer and J. K. G. Kramer. 1997. Effect of nigericin, monensin, and tetronasin on biohydrogenation in continuous flow- through ruminal fermenters. J. Dairy Sci. 80: 921-928.

Harwood, D. 2004. Diseases of dairy goats. In Practice 26, pp. 248-259.

Ipharraguerre, I. R. and J. H. Clark. 2003. Usefulness of ionophores for lactating dairy cows: A review. Anim. Feed Sci. Technol. 106:39-57.

Johnson, A. M., E. M. Rohlfs and L. M. Silverman. 1999. Proteins, In: Tietz's Textbook of Clinical Pathology, 3rd Ed. W.B. Saunders Company, Philadelphia, USA, pp. 477-540.

McMurray, C. H., W. J. Blanchflower and D. A. Rice. 1984. Automated kinetic method for D-3-hydroxybutyrate in plasma or serum. Clin. Chem. 30:421-425.

NRC (National Research Council). 2007. Nutrient requirements of small ruminants, sheep, goats, cervids, and new world camelids. The National Academic press, washington DC, USA.

Petersson-Wolfe, C. S., K. E. Leslie, T. Osborne, B. W. McBride, R. Bagg and G. Vessie. 2007. Effect of monensin delivery method on dry matter intake, body condition score, and metabolic parameters in transition dairy cows. J. Dairy Sci. 90:1870-1879.

Phipps, R. H., J. I. Wilkinson, L. J. Jonker, M. Tarrant, A. K. Jones and A. Hodge. 2000. Effect of monensin on milk production of Holstein-Friesian dairy cows. J. Dairy Sci. 83:2789-2794.

Plaizier, J. C., A. M. Fairfield, P. A. Azevedo, A. Nikkhah, T. F. Duffield, G. H. Crow, R. Bagg, P. Dick and B. W. McBride. 2005. Effects of monensin and stage of lactation on variation of blood metabolites within twenty-four hours in dairy cows. J. Dairy Sci. 88:3595-3602.

Poos, M. I., T. L. Hanson and T. J. Klopfenstein. 1979. Monensin effects on diet digestibilitiy, ruminal protein bypass and microbial protein synthesis. J. Anim. Sci. 48:1516.

Ratge, D., K. P. Kohse and H. Wisser. 1986. Measurement of magnesium in serum and urine with a random access analyzer by use of a modified Xylidyl blue-1 procedure. Clin. Chem. Acta 159:197-203.
Sauer, F. D., J. K. G. Kramer and W. J. Cantwell. 1989. Antiketogenic effects of monensin in early lactation. J. Dairy Sci. 72:436-442.

Schanne, F. A. X., A. B. Kane, E. E. Young and J. L. Farber. 1979. Calcium dependence of toxic cell death: A final common pathway. Science 206:700-702.

Schelling, G. T. 1984. Monensin: mode of action in the rumen. J. Anim. Sci. 58:1518-1527.

Schlumbohm, C. and J. Harmeyer. 2004. Hyperketonemia impairs glucose metabolism in pregnant and non- pregnant Ewes. J. Dairy sci. 87:350-358.

Scott, R., S. R. Starnes, J. W. Spears, M. A. Froetschel and W. J. Jr Croom. 1984. Influence of monensin and lasalocid on mineral metabolism and ruminal urease activity in steers. J. Nutr. 114:518-525.

Shetaewi, M. M. and T. T. Ross. 1991. Effects of concentrate supplementation and lasalocid on serum chemistry and hormone profiles in Rambouillet ewes. Small Rum. Res. 4:365-377.

Simpson, M. E. 1978. Effects of certain antibiotics on in vitro cellulose digestibility and volatile fatty acid production by ruminal microorganisms. J. Anim. Sci. 47(Suppl. 1):439.

Smith, J. B. and E. Rosengurt. 1978. Serum stimulates the Na-K pump in quiescent fibroblasts by increasing $\mathrm{Na}$ entry. Proc. Natl. Acad. Sci. USA 75:5560.

Taghipoor, B., H. A. Seifi, M. Mohri, N. Farzaneh and A. A. Naserian. 2011. Effect of prepartum administration of monensin on metabolism of pregnant ewes. Livest. Sci. 135:231-237.

Tomas, H. 1998. Clinical Laboratory Diagnostics. 1sted., THBooks, Verlagsgesellschaft, Frankfurt. pp. 208-214 and 644647.

Tyler, J. W., D. F. Wolfe and R. Maddox. 1992. Clinical indications for dietary ionophores in ruminants. Compend. Contin. Educ. Pract. Vet. 14:989-993.

Wagner, J. R., H. B. Green, J. T. Symanowski, J. I. D. Wilkinson, J. S. Davis, M. R. Himstedt, M. S. Allen, E. Bock, J. J. Brennan, H. H. Head, J. J. Kenelly, J. N. Nielsen, J. E. Nocek, M. J. Van Der List and L. W. Whitlow. 1999. Effect of monensin on feed intake, body weight, and body condition in dairy cows. J. Dairy Sci. 82(Suppl. 1):75.

Wang, Z. and L. A. Goonewardene. 2004. The use of mixed models in the analysis of animal experiments with repeated measure data. Can. J. Anim. Sci. 84:1-11. 